DOI: $10.17805 /$ trudy.2017.4.5

\title{
ПРОФЕССИОНАЛЬНАЯ ДЕФОРМАЦИЯ ПРЕПОДАВАТЕЛЕЙ ВЫСШЕЙ ШКОЛЫ
}

\author{
Н. И. Федотова \\ Московский гуманитарный университет
}

Аннотация: В статье проанализирована проблема изменение психической структуры, качеств личности (поведение, способов общения, стереотипов восприятия, характера, ценностных ориентаций и др.) под влиянием выполнения профессиональной деятельности.

Ключевые слова: профессиональная деформация; эмоциональное выгорание; преподаватели высшей школы; профессиональная деятельность

\section{PROFESSIONAL DEFORMATION OF TEACHERS OF HIGHER EDUCATION INSTITUTIONS}

\author{
N. I. Fedotova \\ Moscow University for the Humanities
}

\begin{abstract}
The article analyses the problem of change of the mental structure and qualities of the person (behaviour, ways of communication, stereotypes of perception, character, value orientations, etc.) under the influence of performance of professional activity.

Keywords: professional deformation; emotional burning out; teachers of higher school; professional activity
\end{abstract}

Профессиональная деформация сегодня является одной из достаточно острых проблем, как в силу распространенности, так и в силу негативных последствий для человека. Известно, что сам по себе труд способен оказывать благотворное и облагораживающее воздействие на личность. Ежедневно, на протяжении многих лет, под влиянием трудовой деятельности совершенствуются не только профессиональные знания и навыки, но и формируются профессиональные привычки, определенный склад мышления и стиль общения. Данные многочисленных исследований показали, что труд оказывает не только положительное влияние на психику личности, но и приводит к появлению профессиональной усталости, снижению работоспособности, утрате профессиональных навыков и умений. Таким образом, на стадии профессионализации человека возникает профессиональная деформация. 
В настоящее время система высшего образование в России находится на этапе интенсивного развития и усовершенствования. Повышаются требования к преподавателям вузов и сегодня педагогу высшей школы необходимо уметь принимать нестандартные решения, использовать инновационные подходы в педагогической деятельности, беспрерывно повышать уровень профессиональной компетентности, конструктивно взаимодействовать с учащимися, быть образцом и примером для подражания (Зубаков, Комаров, 2010: 73).

Все вышесказанное создает постоянное напряжение, которое приводит к снижению работоспособности, приводит к физическому утомлению, разочарованию и эмоциональному истощению. У преподавателя возникает необходимость восстанавливать или беречь эмоциональноэнергетические ресурсы, прибегая к тем или иным приемам психологической защиты. Вариантом экономии ресурсов, является - эмоциональное выгорание, которое рассматривается как одна из форм профессиональной деформации личности.

Профессиональная деформация - это неосознанная привычка человека измерять явления окружающего мира в соответствии с профессиональными стандартами. Под влиянием условий труда происходит ослабление или угасание позитивно психических качеств личности. Со временем негативные новообразования личности усиливаются и развиваются в синдроме «эмоционального выгорания». Целью статьи является - теоретический обзор основных причин профессионально-личностных деформаций: каким образом происходит изменение психической структуры личности преподавателя высшей школы, качеств личности (поведение, способов общения, стереотипов восприятия, характера, ценностных ориентаций и др.) под влиянием выполнения профессиональной деятельности.

Профессиональная деятельность преподавателей высшей школы в психологическом плане является одним из наиболее напряженных видов социальной деятельности. Педагоги вузов часто находятся в состоянии хронического напряжения, входят в группу профессий с большим присутствием стресс-факторов, количество которых постоянно растет. Кроме того, труд в преподавателей вуза - наиболее сложная форма трудовой деятельности, требующая значительного объема памяти, напряжения внимания, что еще более повышает нервно-эмоциональное напряжение.

Несмотря на то, что в проблеме профессиональной деформации педагогов еще много малоизученных аспектов, уже накоплен достаточно большой теоретический и опытно-экспериментальный материал по результатам исследований.

Ряд авторов считает, что проблема снижения эффективности профессиональной деятельности преподавателей в последнее время все больше 
рассматривается в связи психоэмоциональными перегрузками, которые они испытывают под влиянием многочисленных эмоциональных факторов. Профессия преподавателя высшей школы связанна с большими нервно-психическими нагрузками, характеризуется высоким уровнем ответственности и напряженности. К специфическим особенностям педагогической деятельности можно отнести: многообразие коммуникативных связей; разнообразие контактов в общении и взаимодействии; постоянную необходимость принимать решения; находить конструктивные пути выхода из конфликта и другие (Водопьянова, Старченкова, 2005; Прокопцева, 2010).

Исследователи считают труд педагога в высокой степени напряженным и связанным с действием экстремальных факторов. На лекциях от преподавателя требуется постоянная собранность, быстрота реакции, владение множеством способов и приемов воздействия на учеников. В своих работах ученые рассматривают педагогическую деятельность как стрессогенную, несущую в себе повышенный риск негативного влияния на субъектов профессионального взаимодействия (Володина, 2010; Загуменных, 2014; Корытова, 2014).

О. С. Зорькина считает, что к фактору, дестабилизирующему преподавательскую деятельность, можно отнести увеличение количества студентов в группах (с которыми он вынужден работать за тот же самый объем заработной платы), а также понижения уровня подготовленности абитуриентов, поступающих на первый курс. В слабых студентов преподаватель вынужден вкладывать намного больше сил, в то время как отдача с их стороны минимальна (Зорькина, 2012: 138).

Т. В. Володина и Г. С. Корытова к основным стрессорам, обуславливающим профессиональную деформацию педагога, относят ежедневную психологическую перегрузку, самоотверженную помощь, высокую ответственность за учеников, ролевые конфликты, поведение «трудных» учащихся (Володина, 2014; Корытова, 2014).

К числу причин, негативно влияющих на возникновение профессионально-личностных деформаций у педагога, Э. Э. Сыманюк и А. А. Печеркина относят: повышенную продолжительность рабочего дня; острый дефицит времени; высокую нервно-психическую напряженность педагогической деятельности; социальную ответственность; восприятие и переработку разнообразной и многочисленной информации; авторитарный стиль руководства; напряженные отношения в педагогическом коллективе (Сыманюк, Печеркина, 2010).

Н. А. Загуменных к особенностям педагогической деятельности относит: психоэмоциональные перегрузки, отсутствие эмоциональной 
разрядки, повышенные нагрузки на зрительный, голосовой и слуховой аппарат (Загуменных, 2014).

Учебно-методическая деятельность преподавателей вузов связана с подготовкой многочисленной документации, что порой заслоняет общение и учебное взаимодействие со студентами, способствует развитию формального подхода к обучению (Сыманюк, Печеркина, 2010: 84).

Следует отметить, что одним из главных профессиональных требований в деятельности преподавателя вуза является следование этическим нормам. Важность данного требования вытекает из специфики педагогической деятельности, а именно - социального значения педагога как трансформатора культуры, нравственных ценностей, примера, образца для подражания и т. д. Соблюдение этических норм обуславливает повышенную эмоциональную нагрузку на специалиста образовательной сферы.

Предпосылки развития профессионально-личностных деформаций коренятся уже в неосознаваемых мотивах выбора педагогической профессии: стремление к власти, доминирование и самоутверждения. Степень выраженности деформации педагога определяются стажем работы, содержанием педагогической деятельности, а также индивидуальнопсихологическими особенностями личности (Зотова, 2013).

Анализ педагогической и психологической литературы показал, что сегодня многие преподаватели вуза не удовлетворены профессиональным статусом, низкой зарплатой, испытывают страх потерять работу изза сокращения рабочих мест. У большинства преподавателей отсутствует условия для самореализации. Кроме того, сегодня деятельность специалистов образовательной сферы рассматривают в качестве рыночной услуги при неизменно высоких требованиях к личностным и профессиональным качествам педагога.

В качестве основных проблем современного педагога Н. В. Козлова и Е. Н. Вержицкая выделяют отсутствие позитивного отношения к нововведениям, психологической готовности к профессиональной деятельности в новых экономических условиях; падение престижа педагогической деятельности; отсутствие возможностей и стимулов для профессиональной самореализации и т. д. (Козлова, Вержицкая, 2010: 178).

Следует отметить, что сегодня профессиональная деятельность педагога приобретает особую значимость. В результате развития системы образования возрастает нагрузка на специалистов образовательной сферы, а именно:

- переход к новым образовательным стандартам предъявляет новые требования к профессиональной компетентности учителя;

• внедрение инновационных технологий образования обуславливает эмоциональную изношенность педагога; 
• внедрение новой системы оплаты труда вызывает непонимание и, как следствие - недовольство;

• новые требования к педагогу как к специалисту, имеющему практический опыт и постоянно повышающему свою квалификацию, приводят к возрастающей информационной и интеллектуальной нагрузке (Сыманюк, Печеркина, 2010).

Профессиональная деформация у представителей педагогической профессии, по данным исследований Э. Э. Сыманюк, А. А. Печеркина, может также проявляться на четырех уровнях:

1. Общепедагогические деформации характеризуются сходными изменениями личности у всех лиц, занимающихся педагогической деятельностью;

2. Типологические деформации появляются, когда особенности личности преподавателя растворяются в соответствующих компонентах педагогической деятельности. Так педагоги, преподающие гуманитарные дисциплины, отличаются эмоциональностью, раскованностью, большой эмпатией. Это педагоги-коммуникаторы. Они общительны, говорливы, стремятся обсуждать проблемы с учениками. Педагоги-интеллигенты любят мудрствовать, философствовать, читать нотации. Организаторы склонны командовать и подчинять себе других;

3. Специфические или предметные деформации обусловлены спецификой преподаваемого предмета. Например, преподаватель математики более сдержан по сравнению с преподавателем литературы;

4. Индивидуальные деформации проявляются из-за индивидуальных особенностей личности педагога (Сыманюк, Печеркина, 2010) .

Таким образом, у каждого преподавателя в зависимости от преподаваемого предмета и личностных свойств характера встречаются различные типы деформации.

Л.М.Зотовавыделяетнесколькофакторов развитияпрофессиональноличностных деформаций в педагогической сфере:

1. Объективные, связанные с социально-профессиональной средой: социально-экономической ситуацией, имиджем и характером профессии, учебно-пространственной средой.

2. Субъективные, обусловленные личностными особенностями педагога и обучаемых, характером их взаимоотношений.

3. Объективно-субъективные, порождаемые системой и организацией профессионально-образовательного процесса, качеством управления, профессионализмом руководителя (Зотова, 2013).

Профессиональная деформация первоначально начинает проявляться в самой личности педагога, а затем через поведение отражается на его профессиональной деятельности и ближайшем окружении. Н. В. Про- 
копцева считает, что у специалиста образовательной сферы наблюдается снижение продуктивной трудовой деятельности, неудовлетворенность жизнью и социальным окружением (Прокопцева, 2010).

Исследователями Н. И. Медведевой и И. А. Усачевой были выделено, что основными негативными составляющими профессиональной деформации личности педагога являются такие качества, как профессиональная агрессия, авторитарность, демонстративность, консерватизм, профессиональный догматизм, сверхконтроль, профессиональная индифферентность, социальное лицемерие, информационная пассивность (Медведева, Усачева, 2012).

Так профессиональная агрессия у педагогов проявляется в отсутствии стремления учитывать чувства, права и интересы учащихся. Агрессивность проявляется в иронии, насмешках и навешивании ярлыков. Обычно данная форма деформации обнаруживается у преподавателей с ростом стажа профессиональной деятельности, когда усиливаются стереотипы мышления.

Авторитарность - деформирующее качество личности педагога, которое проявляется в использовании распоряжений, рекомендаций, указаний ученикам. Авторитарные педагоги нетерпимы к критике и склонны проявлять высокомерие.

Демонстративность проявляется в эмоционально окрашенном поведении, желании нравиться, стремлении быть на виду. Эта тенденция реализуется в демонстрации своего превосходства, в оригинальном поведении, в позах, поступках. Такой стиль поведения педагога снижает эффективность профессиональной деятельности.

Развитию консерватизма способствует то обстоятельство, что педагог в процессе своей трудовой деятельности применяет одни и те же формы и методы обучения. У преподавателя формируется неприятие чужого педагогического опыта и инновационных преобразований.

Профессиональный догматизм характеризуется снижением уровня интеллекта, обусловливается особенностями характера личности. Эта черта формирует у педагога стереотипное решение проблем без учета особенностей проблемной ситуации.

Сверхконтроль проявляется в чрезмерном сдерживании своих чувств, подозрительной осмотрительности, скурпулезном контроле деятельности учащихся. В результате у педагога возникает внутреннее напряжение.

Профессиональная индифферентность развивается вследствие эмоциональной усталости и отрицательного опыта от общения с учащимися. При наличии такого вида деформации педагог отличается эмоциональной сухостью, равнодушием. Индифферентность развивается с годами и 
характерна для черствых, закрытых людей, которые испытывают трудности в общении.

Социальное лицемерие обусловлено необходимостью оправдывать высокие нравственные ожидания учащихся и взрослых, пропагандировать моральные принципы и нормы поведения.

Информационная пассивность проявляется в нежелании совершенствовать свои профессиональные навыки, прекращении самообразования и самовоспитания (Медведева, Усачева, 2012).

Профессиональные деформации развиваются постепенно и долгое время могут оставаться незаметными. С увеличением стажа работы негативные новообразования личности усиливаются и развиваются в синдроме «эмоционального выгорания». Сгорание педагогов проявляется в виде трех стадий. Так, на первой стадии наблюдаются приглушения эмоций, утрата частоты чувств. Затем возникает негативное отношение к коллегам по работе, своим воспитанникам. Если на первых порах неприязнь к окружающим людям можно сдерживать, то затем скрывать свое раздражение удается с трудом. Третья стадия (полное сгорание) выливается в полное отношение ко всему. Человек не способен сосредоточиться, жизнь кажется бессмысленной и неуправляемой (Прокопцева, 2010).

Подытоживая вышесказанное, можно констатировать, что содержание и условия реализации педагогической деятельности требуют повышенной мобилизации внутренних ресурсов преподавателя вуза. Специфика труда специалиста образовательной сферы, связанна со сложностью и насыщенностью профессионального взаимодействия, с высокой моральной и нравственной ответственностью, с необходимостью работы в психологически сложных и постоянно меняющихся ситуациях. Постоянное повышенное требование к профессиональным качествам преподавателя, социально-экономические и политические преобразования, инспекционные проверки, аттестация экспертиза и другие серьезные процедуры влияют на жизненный эмоциональный фон личности педагога. Исследователи схожи во мнении, что у специалистов образовательной сферы отсутствует позитивное отношение к нововведениям в системе образования.

Анализ научной литературы показал, что большинство преподавателей вузов, психологически не готовы к профессиональной деятельности в новых экономических условиях. Разочарование и порой незаслуженные упреки со стороны руководства, сомнения в правильности профессионального выбора, трудности в личной жизни вызывают боль и обиду, провоцируют стресс и приводят к негативным новообразованиям. Также, низкая оплата труда и относительно невысокий статус преподавателя представляют собой факторы, способствующие профессиональной 
деформации. Профессиональные деформации развиваются постепенно и долгое время могут оставаться незаметными. Возникновение и развитие профессионально-личностных деформаций снижает продуктивность педагогической деятельности, отрицательно сказывается на профессиональной мотивации и педагогической позиции преподавателя, мешает проявлению и реализации его профессионально значимых качеств.

\section{СПИСОК ЛИТЕРАТУРЫ}

Водопьянова, Н. Е., Старченкова, Е. С. (2005) Синдром выгорания: диагностика и профилактика. СПб. : Питер. 276 с.

Володина, Т. В. (2010) Особенности профессиональных деструкций у педагогов // Вектор науки Тольяттинского государственного университета. № 1(1). С. 54-58.

Загуменных, Н. А. (2014) Психологическая поддержка педагога при проявлении синдрома эмоционального выгорания // Сборники конференций НИЦ Социосфера. Тема выпуска: Роль психолого-педагогического знания в решении проблем развития образования: Материалы международной научно-практической конференции (заочной) 16 июня 2014 года. № 42. С. $163-169$.

Зорькина, О. С. (2012) К проблеме профессиональной деформации педагогов высшей школы (на примере преподавателей иностранного языка) //Актуальные проблемы филологии и методики преподавания иностранных языков. № 6. С. 136-144.

Зотова,Л.М.(2013)Профессиональныедеформацииженщин-педагога как предмет педагогического исследования // Гуманитарные и социальные науки. № 3. С. 158-163.

Зубаков, М. Г., Комаров В. В. (2010) Синдром эмоционального выгорания как проявление профессиональной деформации // Психолог и вызовы современного мира материалы VIII международного семинара молодых ученных и аспирантов / отв. ред. Н. А. Коваль. Тамбов : БизнесНаука-Общество. 176 с. С. 73-80.

Козлова, Н. В., Вержицкая, Е. Н. (2010) Личностно-профессиональное развитие педагогов в условиях модернизации образования // Вестник Томского государственного университета. № 341. С. 178-180.

Корытова, Г. С. (2014) Профессиональная деформация личности в педагогической деятельности // Вестник Томского государственного педагогического университета. № 1 (142). С. 13-20.

Медведева, Н. И., Усачева, И. А. (2012) Диагностика профессиональных деформаций личности учителя общеобразовательной школы // Мир образования - образование в мире. № 1. С. 184-189.

Прокопцева, Н. В. (2010) Профилактика профессиональной деформации педагога // Высшее образование в России. № 2. С. 152-155. 
Сыманюк, Э. Э., Печеркина, А. А. (2010) Противодействие профессиональным деформациям // Народное образование. № 9. С. 265-269.

Дата поступления: 16.07.2017 2.

Федотова Наталья Игоревна - кандидат психологических наук, доцент кафедры педагогики и психологии высшей школы Московского гуманитарного университета. Адрес: 111395, Россия, г. Москва, ул. Юности, д. 5 Тел.: +7 (499) 374-74-59. Эл. адрес: fedotova1973@mail.ru

Fedotova Natalya Igorevna, Candidate of Psychology, Associate Professor, Department of Pedagogy and Psychology of Higher School, Moscow University for the Humanities. Postal address: 5, Yunosti St., Moscow, Russian Federation 111395. Tel.: +7 (499) 374-74-59.E-mail: fedotova1973@mail.ru

\section{Для цитирования:}

Федотова Н. И. Профессиональная деформация преподавателей высшей школы [Электронный ресурс] // Научные труды Московского гуманитарного университета. 2017, № 4. URL: http://journals.mosgu.ru/trudy/article/view/528 (дата обращения: дд.мм. гг.). DOI: 10.17805/trudy.2017.4.5 